\title{
An Assessment of the Efficacy and Safety of Dapsone Gel: Study in a Local Setting
}

\author{
Dr. Rafiqul Islam ${ }^{1 *}$, Dr. Md. Nazrul Islam², Dr. Mohammed Mosharraf Hossain ${ }^{3}$
}

${ }^{12}$ Assistant Professor, Department of Dermatology, Mymensingh Medical College, Mymensingh, Bangladesh

${ }^{3}$ Assistant Professor, Department of Dermatology, Shahid Syed Nazrul Islam Medical College, Kishoreganj, Bangladesh

DOI: $10.36347 /$ sjams.2021.v09i04.012

| Received: 08.02.2021 | Accepted: 01.04.2021 | Published: 13.04.2021

*Corresponding author: Dr. Rafiqul Islam

Abstract

Original Research Article

Introduction: Acne vulgaris is a long-term skin condition that occurs when dead skin cells and oil from the skin clog hair follicles. Typical features of that condition included blackheads or whiteheads, pimples, oily skin and possible scarring. The aim of the study was to assess the efficacy and safety of dapsone gel in the Treatment of Acne Vulgaris. Method: A clinical trial was carried out at Upazilla Health Complex, Fulpur, Mymensingh during the period from January 2018 to December 2018. Total fifty (50) patients of clinically diagnosed mild to moderate acne vulgaris were enrolled and thirty (30) of Group I patients were treated by dapsone gel and another thirty of Group II patients were treated by Clindamycin cream over 28 days in patients with moderate acne vulgaris. Result: At baseline mean number of comedones in Group I and Group II were 13.11 \pm 3.67 and $12.12 \pm 3.61$, respectively $(\mathrm{p}=0.415)$ and at final follow-up $4.10 \pm 4.11$ and $4.50 \pm 3.10$ in each group $(p>0.05)$. At baseline mean number of papules in Group I and Group II were $18.11 \pm 9.48$ and 19.01 \pm 13.44 , respectively $(\mathrm{p}=0.725)$ and at final follow-up 8.02 \pm 7.69 and 8.03 $\pm 9.68(\mathrm{p}>0.05)$. At baseline mean number of pustules in Group I and Group II were $0.49 \pm 1.43$ and $0.50 \pm 1.31$, respectively ( $\mathrm{p}=0.897)$ and at final follow-up $0.08 \pm 0.36$ and 0.00 ( $>>0.05$ ). At baseline mean of total acne score was $29.96 \pm 14.23$ and $30.90 \pm 17.17$ in Group I and B and at final follow-up, it was $11.87 \pm 12.04$ and $11.20 \pm 13.85$, respectively in Group I and B ( $>>0.05)$. Percent reduction of acne severity from baseline to final follow-up was $69.20 \pm 23.41$ in Group I and $74.77 \pm 23.30$ in Group II ( $\mathrm{p}=0.393$ ). At final follow-up, $56.7 \%$ of Group I and $63.3 \%$ of Group II achieved excellent response and $13.3 \%$ of Group I and $16.7 \%$ of Group II achieved a good response. Conclusion: The study can conclude that dapsone gel was found to be more effective than Clindamycin cream in the treatment of acne vulgaris. This study demonstrated lower systemic exposure with dapsone gel formulations than with Clindamycin cream.

Keywords: Efficacy, Safety, Dapsone gel, Clindamycin cream, Acne Vulgaris.

Copyright $(\mathcal{C} 2021$ The Author(s): This is an open-access article distributed under the terms of the Creative Commons Attribution 4.0 International License (CC BY-NC 4.0) which permits unrestricted use, distribution, and reproduction in any medium for non-commercial use provided the original author and source are credited.

\section{INTRODUCTION}

Acne vulgaris is a long-term skin condition which happens when dead skin cells and oil from the skin clog hair follicles. It is the most 'common inflammatory ltrewq1 disease characterized by comedones; papules; pustules; inflamed nodules; superficial pus-filled cysts; and (in extreme cases) canalizing and deep, inflamed, sometimes purulent sacs [1]. Lesions are commonest on the face, but the neck, chest, upper back, and shoulders may additionally be affected. Adolescents and adults with acne have higher rates of tension or anxiety, low self-worth, and depression than those without acne [2]. Also, adults with severe acne have higher unemployment rates than age-matched controls without acne [3]. There are different treatment options available for patients with acne. All approaches have advantages and disadvantages both and not all approaches are suitable for every patient [4]. The treatment goals are directed to scale back the activity of the sebaceous glands, normalize follicular proliferation, reduce bacterial colonization, and control inflammation [5, 6]. Because of the utilization of topical and systemic antibiotics for acne, the incidence of antibiotic-resistant Propionibacterium acnes is increasing worldwide. Topical benzoyl peroxide (BPO) is used as an alternative to antibiotics for the treatment of acne [7, 8]. Benzoyl peroxide is a powerful antimicrobial agent which destroys both surface and ductal bacterial organisms and yeasts. Its lipophilic properties permit penetration of the pilosebaceous duct and its efficacy is to an excellent extent, against superficial inflammatory lesions. It (BPO) gets decomposed to release free oxygen radicals, which have potent bactericidal activity within the sebaceous follicles and anti-inflammatory 
action. It also has effects on non-inflammatory lesions by reducing follicular hyperkeratosis to a point. They are not related to antimicrobial resistance and are active against fully sensitive and resistant strains of P. acnes [9-11].To treat mild to moderate acne, it can be used alone or in combination with topical antibiotics and topical [12] retinoids.1Clindamycin improves acne by reducing the levels of $P$. acnes and decreasing inflammation [13,14]. The advantages of this combination therapy are - keratolytic action of BPO is possibly synergistic with the antibacterial activity of clindamycin $[15,16]$. This study aims to assess the efficacy and safety of dapsone gel on the Treatment of Acne Vulgaris.

\section{OBJeCTIVES}

- To assess the efficacy and safety of dapsone gel in the Treatment of Acne Vulgaris in Bangladesh

\section{Method And Materials}

A clinical trial was conducted in Upazilla Health Complex, Fulpur, Mymensingh during the period from January 2018 to December 2018. Acne vulgaris patients during the study period were enrolled in the study. Those patients, who matched the inclusion and exclusion criteria, were selected for the study. Inclusion criteria of patient selection were patients clinically diagnosed as acne vulgaris who given informed written consent to be included in the study, aged $\geq 12$ years of both sexes. Data were collected by face-to-face interviewing and were recorded in a predesigned questionnaire. Information was taken including a medical history and clinical examination. Baseline laboratory investigations were carried out for purpose of exclusion and monitoring of side effects. Laboratory investigations included with complete blood counts, liver function tests, serum creatinine, random blood sugar level, and serum cholesterol and triglyceride level. Total fifty (50) patients with clinically diagnosed mild to moderate acne were enrolled and divided into Group I and Group II. Twenty-five of Group I patients were treated with dapsone gel and twenty-five of Group II patients were treated with Clindamycin cream. Participants were clinically assessed every month for three months. The severity index of the disease was calculated and clinical photographs were taken in time. Clinical assessment and the severity index were calculated at the end of the last month. Then the patient was followed up second month in the post-treatment period to assess for any recurrence. A four point scale was used to measure the level of response during treatment, if $>75 \%$ clearExcellent response; if $50-75 \%$ clear- good response if $25-50 \%$ clear fair response; if $<25 \%$ clear poor response. Safety, tolerability and efficacy were assessed through evaluations of local facial tolerability and adverse events. In each follow-up, clinical evaluation of the patients was undertaken to assess the Efficacy and
Safety of dapsone gel in the Treatment of Acne Vulgaris. Data were analyzed by computer software package SPSS and the level of significance was measured. Statistical significance (p-value) was set at $<0.05$ level and confidence interval at $95 \%$ level.

\section{RESULTS}

Twenty-five of Group I patients were treated with dapsone gel and twenty-five of Group II patients were treated with Clindamycin cream. Table 1 shows that the Mean \pm SD of age of onset of acne was $20.01 \pm 3.43$ years and 18.02 \pm 2.52 years in Group I and Group II, respectively $(\mathrm{p}=0.345)$. The mean duration of disease was $17.04 \pm 16.77$ months and 27.00 \pm 39.91 months in Group I and Group II, respectively ( $\mathrm{p}=0$. 213). Facial lesions were present in $96.0 \%$ of Group I and $100.0 \%$ of Group II, neck lesions were present in $6.7 \%$ and Nose lesions in $3.3 \%$ ( $p>0.05)$ in each group (Table-2). At baseline mean number of comedones in Group I and Group II were 13.11 \pm 3.67 and 12.12 \pm 3.61 , respectively $(\mathrm{p}=0.415)$. At 1 st follow-up the mean number of comedones in Group I and Group II was $7.80 \pm 4.11$ and $7.77 \pm 4.08$, respectively, at 2nd followup, it was $6.10 \pm 4.03$ and $5.63 \pm 4.16$ and at final followup $4.17 \pm 4.02$ and $3.47 \pm 4.00$ in each group $(p>0.05)$. At baseline mean number of papules in Group I and Group II were $18.11 \pm 9.48$ and $19.01 \pm 13.44$ respectively $(\mathrm{p}=0$. 725 ). At 1 st follow-up, the mean number of papules in

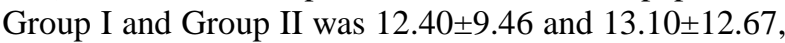
respectively, at 2nd follow-up it was $9.97 \pm 8.73$ and $10.10 \pm 11.17$ and at final follow-up 7.63 \pm 8.08 and $7.73 \pm 9.98$, respectively ( $>0.05)$ and Group II was $0.49 \pm 1.43$ and $0.50 \pm 1.31$, respectively $(p=0$. 922). At 1st follow-up the mean number of pustules in Group I and Group II was $0.30 \pm 0.88$ and $0.30 \pm 0.75$, respectively, at 2 nd follow-up, it was $0.17 \pm 0.59$ and $0.10 \pm 0.31$ and at final follow up $0.08 \pm 0.36$ and 0.00 , respectively $(p>0.05)$ (Table-3). At baseline mean of total acne score (acne score of comedones, papules, and pustules) was $29.96 \pm 14.23$ and $30.90 \pm 17.17$ in Group I and Group II, respectively. At 1st follow-up it was $20.50 \pm 13.64$ and $21.17 \pm 16.94$, respectively in Group I and Group II, at 2nd follow-up it was $16.23 \pm 12.74$ and $15.83 \pm 15.29$ and at final follow up it was $11.87 \pm 12.04$ and $11.20 \pm 13.85$, respectively in Group I and Group II $(p>0.05)$. Percent reduction of acne severity from baseline to final follow-up was $69.20 \pm 23.41$ in Group I and $74.77 \pm 23.30$ in Group II $(p=0.393)$, (Table 4). At 1st follow-up, $4.0 \%$ of both groups got an excellent response, $8.0 \%$ of Group I and $24.0 \%$ Group II got a good response, $60.0 \%$ of Group I and $40.0 \%$ of Group II got a fair response, and $28.0 \%$ of Group I and $32.0 \%$ of Group II got a poor response $(\mathrm{p}=0.298)$. At 2 nd follow-up, $12.0 \%$ of Group I and $32.0 \%$ of Group II got an excellent response, $48.0 \%$ of Group I and $40.0 \%$ of Group II got a good response, $32.0 \%$ of Group I and $20 \%$ of Group II got a fair response and $8.0 \%$ of Group I and $8.0 \%$ of Group II got a poor response $(\mathrm{p}=0.513)$. At final follow-up, $56.0 \%$ of Group I and $64.0 \%$ of 
Rafiqul Islam et al; Sch J App Med Sci, Apr, 2021; 9(4): 549-553

Group II achieved an excellent response, $12.0 \%$ of Group I and $16.0 \%$ of Group II achieved a good response, $24.0 \%$ of Group I and $16.0 \%$ of Group II achieved fair response and $8.0 \%$ of Group I and $4.0 \%$ of Group II achieved poor response ( $\mathrm{p}=0.794)$, (Table 5).

Table-1: Mean and standard deviation of age at first acne appeared (yrs.) and duration of Acne (months). (n=50)

\begin{tabular}{|l|l|l|l|}
\hline \multirow{2}{*}{ Characteristics } & \multicolumn{2}{|c|}{ Group } & \multirow{2}{*}{ p-value } \\
\cline { 2 - 3 } & Group I & Group II & \\
\hline Age at first acne appeared (yrs.) & $20.01 \pm 3.43$ & $18.02 \pm 2.52$ & 0.345 \\
\hline Duration of acne (months) & $17.04 \pm 16.77$ & $27.00 \pm 39.91$ & 0.213 \\
\hline
\end{tabular}

Table-2: Distribution of groups by the site of lesion $(n=50)$

\begin{tabular}{|l|l|l|l|}
\hline \multirow{2}{*}{ Site } & Group & \multirow{2}{*}{ p-value } \\
\cline { 2 - 3 } & Group I & Group II & \\
\hline Face & $24(96.0 \%)$ & $25(100.0 \%)$ & 0.276 \\
\hline Neck & $2(6.7 \%)$ & $2(6.7 \%)$ & 0.888 \\
\hline Nose & $1(3.3 \%)$ & $1(3.3 \%)$ & 0.888 \\
\hline
\end{tabular}

Table-3: Mean and standard deviation of comedones papules and pustules baseline and subsequent follow up $(\mathbf{n}=\mathbf{5 0})$

\begin{tabular}{|l|l|l|l|}
\hline \multirow{2}{*}{ Characteristics } & \multicolumn{2}{|c|}{ Group } & \multirow{2}{*}{ p-value } \\
\cline { 2 - 3 } & Group I & Group II & \\
\hline Mean number of comedones & & & \\
\hline Baseline & $13.11 \pm 3.67$ & $12.12 \pm 3.61$ & 0.415 \\
\hline 1st follow-up & $7.80 \pm 4.11$ & $7.77 \pm 4.08$ & 0.879 \\
\hline 2nd follow-up & $6.10 \pm 4.03$ & $5.63 \pm 4.16$ & 0.714 \\
\hline Final follow-up & $4.10 \pm 4.11$ & $4.50 \pm 3.10$ & 0.498 \\
\hline Mean number of papules & & & \\
\hline Baseline & $18.11 \pm 9.48$ & $19.01 \pm 13.44$ & 0.725 \\
\hline 1st follow-up & $12.40 \pm 9.46$ & $13.10 \pm 12.67$ & 0.713 \\
\hline 2nd follow-up & $9.97 \pm 8.73$ & $10.10 \pm 11.17$ & 0.878 \\
\hline Final follow-up & $8.02 \pm 7.69$ & $8.03 \pm 9.68$ & 0.934 \\
\hline Pustules & & & \\
\hline Baseline & $0.49 \pm 1.43$ & $0.50 \pm 1.31$ & 0.897 \\
\hline 1st follow-up & $0.30 \pm 0.88$ & $0.30 \pm 0.75$ & 0.888 \\
\hline 2nd follow-up & $0.17 \pm 0.59$ & $0.10 \pm 0.31$ & 0.614 \\
\hline Final follow-up & $0.08 \pm 0.36$ & 0 & 0.387 \\
\hline
\end{tabular}

Table-4: Mean of total acne score at different follow-up visits. $(n=50$

\begin{tabular}{|l|l|l|l|}
\hline \multirow{2}{*}{ Mean of total acne score } & \multicolumn{2}{|l}{ Groups } & \multirow{2}{*}{ p-value } \\
\cline { 2 - 3 } & Group I & Group II & \\
\hline Baseline & $29.96 \pm 14.23$ & $30.90 \pm 17.17$ & 0.756 \\
\hline $1^{\text {st }}$ follow-up & $20.50 \pm 13.64$ & $21.17 \pm 16.94$ & 0.798 \\
\hline $2^{\text {nd }}$ follow-up & $16.23 \pm 12.74$ & $15.83 \pm 15.29$ & 0.782 \\
\hline Final follow-up & $11.87 \pm 12.04$ & $11.20 \pm 13.85$ & 0.7124 \\
\hline $\begin{array}{l}\text { Percent of reduction from } \\
\text { baseline to final follow-up }\end{array}$ & $69.20 \pm 23.41$ & $74.77 \pm 23.30$ & 0.393 \\
\hline
\end{tabular}


Table-5: Distribution of lesions begin to clear by groups in different follow up (n=50)

\begin{tabular}{|c|c|c|c|}
\hline \multirow[t]{2}{*}{ Lesions begin to clear } & \multicolumn{2}{|l|}{ Group } & \multirow[t]{2}{*}{ p-value } \\
\hline & Group A & Group II & \\
\hline \multicolumn{4}{|l|}{$1^{\text {st }}$ follow up } \\
\hline Excellent & $1(4.0 \%)$ & $1(4.0 \%)$ & \multirow[t]{4}{*}{0.298} \\
\hline Good & $2(8.0 \%)$ & $6(24.0 \%)$ & \\
\hline Fair & $15(60.0 \%)$ & $10(40.0 \%)$ & \\
\hline Poor & $7(28.0 \%)$ & $8(32.0 \%)$ & \\
\hline \multicolumn{4}{|l|}{$2^{\text {nd }}$ follow up } \\
\hline Excellent & $3(12.0 \%)$ & $8(32.0 \%)$ & \multirow[t]{4}{*}{0.513} \\
\hline Good & $12(48.0 \%)$ & $10(40.0 \%)$ & \\
\hline Fair & $8(32.0 \%)$ & $5(20.0 \%)$ & \\
\hline Poor & $2(8.0 \%)$ & $2(8.0 \%)$ & \\
\hline \multicolumn{4}{|l|}{$3^{\text {rd }}$ follow up } \\
\hline Excellent & $14(56 \%)$ & $16(64.0 \%)$ & \multirow[t]{4}{*}{0.794} \\
\hline Good & $3(12.0 \%)$ & $4(16.0 \%)$ & \\
\hline Fair & $6(24.0 \%)$ & $4(16.0 \%)$ & \\
\hline Poor & $2(8.0 \%)$ & $1(4.0 \%)$ & \\
\hline
\end{tabular}

\section{DISCUSSION}

In our study, twenty-five of Group I patients were treated with dapsone gel and thirty of Group II patients were treated with Clindamycin cream. The Mean \pm SD of age of onset of acne was 20.01 \pm 3.43 years and 18.02 \pm 2.52 years in Group I and Group II, respectively. Similar results were found in another study by Zaina T. et al.[17] where the mean age was 20.3 years. The mean duration of disease was $17.04 \pm 16.77$ months and 27.00 \pm 39.91 months in Group I and Group II, respectively $(\mathrm{p}=0.213)$. Similar results were found in another study by Al Sabaa HM et al. [18], where the duration of acne ranged from half to 4 years with a mean duration of $1.53 \pm 0.92$. Facial lesions were present in $96.0 \%$ of Group I and $100.0 \%$ of Group II, neck lesions were present in $6.7 \%$, and Nose lesions in $3.3 \%$ ( $p>0.05)$ in each group. At baseline mean number of comedones in Group I and Group II were 13.11 \pm 3.67 and $12.12 \pm 3.61$, respectively $(p=0.415)$. At $1^{\text {st }}$ followup the mean number of comedones in Group I and Group II was 7.80 \pm 4.11 and $7.77 \pm 4.08$, respectively, at $2^{\text {nd }}$ follow-up, it was $6.10 \pm 4.03$ and $5.63 \pm 4.16$ and at final follow-up $4.17 \pm 4.02$ and $3.47 \pm 4.00$ in each group ( $>0.05$ ). In another study of Del Rosso JQ et al.[19], among 20 study people mean non-inflammatory lesion at baseline was $25 \pm 20$, in the follow-up time at $4^{\text {th }}$ week mean non-inflammatory lesion was $22 \pm 25$, in the follow-up time at $10^{\text {th }}$ week mean non-inflammatory lesion was $12 \pm 17$ and in the final follow up time at $16^{\text {th }}$ week mean non-inflammatory lesion was $12 \pm 22$. At baseline mean number of papules in Group I and Group II were $18.11 \pm 9.48$ and $19.01 \pm 13.44$ respectively $(\mathrm{p}=0$. 725 ). At $1^{\text {st }}$ follow-up, the mean number of papules in

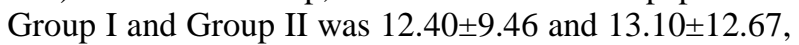
respectively, at $2^{\text {nd }}$ follow-up it was $9.97 \pm 8.73$ and $10.10 \pm 11.17$ and at final follow-up $7.63 \pm 8.08$ and $7.73 \pm 9.98$, respectively $(\mathrm{p}>0.05)$ and Group II was $0.49 \pm 1.43$ and $0.50 \pm 1.31$, respectively $(p=0.922)$. At $1^{\text {st }}$ follow-up mean number of pustules in Group I and
Group II was $0.30 \pm 0.88$ and $0.30 \pm 0.75$, respectively, at $2^{\text {nd }}$ follow-up, it was $0.17 \pm 0.59$ and $0.10 \pm 0.31$, and at final follow up $0.08 \pm 0.36$ and 0.00 , respectively ( $p>0.05)$. In the study of Del Rosso JQ et al.[19], mean inflammatory lesion count (both papules and pustules) at baseline was $34 \pm 26$, mean inflammatory lesion count at $1^{\text {st }}$ follow up was $24 \pm 25$, mean inflammatory lesion count at $2^{\text {nd }}$ follow up was $14 \pm 19$, mean inflammatory lesion count at final follow up was $12 \pm 23$.

At baseline mean of total acne score (acne score of comedones, papules, and pustules) was $29.96 \pm 14.23$ and $30.90 \pm 17.17$ in Group I and Group II, respectively. At 1 st follow-up it was $20.50 \pm 13.64$ and $21.17 \pm 16.94$, respectively in Group I and Group II, at 2nd follow-up it was $16.23 \pm 12.74$ and $15.83 \pm 15.29$ and at final follow up it was $11.87 \pm 12.04$ and $11.20 \pm 13.85$, respectively in Group I and Group II ( $p>0.05)$. In the study of Del Rosso JQ et al. [19], mean total lesion count at baseline was $59 \pm 44$, mean total lesion count at $1^{\text {st }}$ follow up was $46 \pm 49$, mean total lesion count at $2^{\text {nd }}$ follow up was $27 \pm 35$, and mean total lesion count at final follow up was $24 \pm 44$. Percent reduction of acne severity from baseline to final follow-up was $69.20 \pm 23.41$ in Group I and $74.77 \pm 23.30$ in Group II $(\mathrm{p}=0.393)$. At 1 st follow-up, $4.0 \%$ of both groups got an excellent response, $8.0 \%$ of Group I and $24.0 \%$ Group II got a good response, $60.0 \%$ of Group I and $40.0 \%$ of Group II got a fair response, and $28.0 \%$ of Group I and $32.0 \%$ of Group II got a poor response $(\mathrm{p}=0.298)$. At 2nd follow-up, $12.0 \%$ of Group I and $32.0 \%$ of Group II got an excellent response, $48.0 \%$ of Group I and $40.0 \%$ of Group II got a good response, $32.0 \%$ of Group I and $20 \%$ of Group II got a fair response and $8.0 \%$ of Group I and $8.0 \%$ of Group II got a poor response $(\mathrm{p}=0.513)$. At final follow-up, $56.0 \%$ of Group I and $64.0 \%$ of Group II achieved an excellent response, $12.0 \%$ of Group I and $16.0 \%$ of Group II achieved a good response, $24.0 \%$ of Group I and $16.0 \%$ of Group II 
Rafiqul Islam et al; Sch J App Med Sci, Apr, 2021; 9(4): 549-553

achieved fair response and $8.0 \%$ of Group I and $4.0 \%$ of Group II achieved a poor response.

\section{Limitations of the study}

This was a single-center study with small sample size. So, the study results might not be reflected in the whole country.

\section{Conclusion and Recommendations}

Study found that clindamycin cream was to be effective in the treatment of acne vulgaris but dapsone gel was found to be superior in efficacy, tolerability and Safety. We suggest multicenter, randomized, doubleblind study with a large sample size.

\section{REFERENCES}

1. Healy E, Simpson N. Fortnightly review acne vulgaris. BMJ. 1994 Mar 26; 308(6932):831-3.

2. Ramrakha S, Fergusson DM, Horwood LJ, Dalgard F, Ambler A, Kokaua J, Milne BJ, Poulton R. Cumulative mental health consequences of acne: 23-year follow-up in a general population birth cohort study. The British journal of dermatology. 2016 Nov; 175(5):1079.

3. Cunliffe WJ. Acne and unemployment. $\mathrm{Br} \mathrm{J}$ Dermatol. 1986; 115:386.

4. Thiboutot D, Zaenglein A, Weiss J. An aqueous gel fixed combination of clindamycin phosphate $1.2 \%$ and benzoyl peroxide $2.5 \%$ for the once-daily treatment of moderate-to-severe acne vulgaris: assessment of efficacy and safety in 2,813 patients. J Am Acad Dermatol. 2008; 59:792-800.

5. Weiss J. Current options of topical treatment of acne vulgaris. Pediatr Dermatol. 2007; 14:480-8.

6. Savage LJ, Layton AM. Treating Acne Vulgaris: Systemic, Local and Combination Therapy. Expert Rev Clin Pharmacol. 2010; 13:563-80.

7. Degitz K, Ochsendorf F. Pharmacotherapy of acne. Pharmacother. 2008; 9:955-71

8. Dutil M. Benzoyl peroxide: enhancing antibiotic efficacy in acne management. Skin Therapy Lett. 2010; 15(10):5-7.

9. Webster GF, Jeyden JJ, McGinley KJ, McArthur WP. Suppression of polymorphonuclear leucocyte chemotactic factor production in Propionibacterium acnes by subminimal inhibitory concentrations of tetracycline, ampicillin, minocycline, and erythromycin. Antimicrob Agents

Chemother.1992; 21:770-2.

10. Kubba A, Bajaj AK, Thappa DM, Sharma R, Vedamurthy M, Dhar S. Acne in India: Guidelines for management - IAA consensus document: Topical antibacterials. Indian J Dermatol Venereol Leprol. 2009; 75:1-62.

11. Michael H, Gold MD. A New, Once-daily, Optimized, Fixed Combination of Clindamycin Phosphate $1.2 \%$ and Low-concentration Benzoyl Peroxide $2.5 \%$ Gel for the Treatment of Moderateto-Severe Acne. J Clin Aesthetic Dermatol. 2009; 2(5):44-8.

12. Choudhury S, Chatterjee S, Sarkar DK, Dutta R N. Efficacy and safety of topical nadifloxacin and benzoyl peroxide versus clindamycin and benzoyl peroxide in acne vulgaris: A randomized controlled trial. Indian J Pharmacol. 2011; 43:628-31.

13. Bojar RA, Cunliffe WJ, Holland KT. The shortterm treatment of acne vulgaris with benzoyl peroxide: effects on the surface and follicular cutaneous microflora. $\mathrm{Br} \mathrm{J}$ Dermatol. 1995; 132:204-8.

14. Lookingbill DP, Chalker DK, Lindholm JS. Treatment of acne with a combination clindamycin/benzoyl peroxide gel compared with clindamycin gel, benzoyl peroxide gel, and vehicle gel: combined results of two double-blind investigations. J Am Acad Dermatol. 1997; 37:5905.

15. Tucker R, Walton $\mathrm{S}$. The role of benzoyl peroxide in the management of acne vulgaris. Pharm J. 2007; 279:48-53.

16. Kligman AM, Leyden JJ, Stewart R. New uses for benzoyl peroxide: a broad-spectrum antimicrobial agent. Int J Dermatol. 1997; 16:413-7.

17. Al-Salama ZT, Deeks ED. Dapsone $7.5 \%$ gel: a review in acne vulgaris. American journal of clinical dermatology. 2017 Feb 1;18(1):139-45.

18. Al Sabaa HM, Abdel-Wahab HM, Hussein AK, Ragaie MH. Dapsone Niosome: A Novel Formulation for Treatment of Mild to Moderate Acne Vulgaris.

19. Del Rosso JQ, Kircik L, Tanghetti E. Management of truncal acne vulgaris with topical dapsone $7.5 \%$ gel. The Journal of clinical and aesthetic dermatology. 2018 Aug;11(8):45. 